\title{
A new generation of versatile chromogenic substrates for high-throughput analysis of biomass-degrading enzymes
}

\author{
Stjepan Krešimir Kračun ${ }^{1 \dagger}$, Julia Schückel ${ }^{1 \dagger}$, Bjørge Westereng ${ }^{1,2,3}$, Lisbeth Garbrecht Thygesen ${ }^{3}$, \\ Rune Nygaard Monrad ${ }^{4}$, Vincent G H Eijsink ${ }^{2}$ and William George Tycho Willats ${ }^{1 *}$
}

\begin{abstract}
Background: Enzymes that degrade or modify polysaccharides are widespread in pro- and eukaryotes and have multiple biological roles and biotechnological applications. Recent advances in genome and secretome sequencing, together with associated bioinformatic tools, have enabled large numbers of carbohydrate-acting enzymes to be putatively identified. However, there is a paucity of methods for rapidly screening the biochemical activities of these enzymes, and this is a serious bottleneck in the development of enzyme-reliant bio-refining processes.

Results: We have developed a new generation of multi-coloured chromogenic polysaccharide and protein substrates that can be used in cheap, convenient and high-throughput multiplexed assays. In addition, we have produced substrates of biomass materials in which the complexity of plant cell walls is partially maintained.

Conclusions: We show that these substrates can be used to screen the activities of glycosyl hydrolases, lytic polysaccharide monooxygenases and proteases and provide insight into substrate availability within biomass. We envisage that the assays we have developed will be used primarily for first-level screening of large numbers of putative carbohydrate-acting enzymes, and the assays have the potential to be incorporated into fully or semi-automated robotic enzyme screening systems.
\end{abstract}

Keywords: Chromogenic substrates, Carbohydrate-active enzymes, High-throughput screening, Biomass degradation, Plant cell walls, Lytic polysaccharide monooxygenases

\section{Background}

Polysaccharide-degrading enzymes including glycosyl hydrolases (GHs) and lytic polysaccharide monooxygenases (LPMOs) are abundant in nature and of major biotechnological importance [1-4]. In particular, the effective utilization of lignocellulosic materials for secondgeneration biofuels and chemical production is heavily reliant on enzymes for plant cell wall deconstruction [5-7]. Advances in genomics, proteomics, and associated bioinformatics have enabled the identification of vast numbers of putative enzymes currently assigned to over 130 families in the carbohydrate-active enzyme (CAZy) database [8]. However, it is estimated that the activity of

\footnotetext{
*Correspondence: willats@plen.ku.dk

${ }^{\dagger}$ Equal contributors

'Department of Plant and Environmental Sciences, Thorvaldsensvej 40, Frederiksberg C 1871, Denmark

Full list of author information is available at the end of the article
}

no more than $20 \%$ of the enzymes in CAZy can be reliably predicted with confidence [9-13], and the gulf between identification and characterisation is rapidly widening. There is therefore a pressing need for fast, cheap and facile techniques to empirically screen enzyme activities and preferably methods that can be integrated with semi- or fully automated colony picking and protein expression systems.

Several techniques already exist for assaying GH and LPMO activities, although all have some limitations. Oligosaccharide products can be analysed using highperformance chromatography, and information on product identities obtained by mass spectrometry [14]. This is a powerful and quantitative approach but low throughput and requires highly specialised equipment and personnel. $\mathrm{GH}$ activities can also be monitored by measuring the generation of reducing ends, for example, using the 
Nelson-Somogyi [15], the 3,5-dinitrosalicylic acid [16], phydroxybenzoic acid hydrazide (PAHBAH) [17] and 3methyl-2-benzothiazolinone hydrazone (MBTH) [18] methods. However, these reducing end assays also have limited throughput and can be prone to side reactions [19]. Chromogenic substrates are available for screening some enzyme activities. For example, para-nitrophenyl (pNP) glycosides can be useful for rapidly assaying GH activities, although these small artificial compounds are of limited use for the study of high molecular weight and sometimes crystalline substrates such as chitin, cellulose and some arabinoxylans $[6,20]$. However, an elegant new method for the colorimetric detection of chitinase and cellulase activities was recently described [21]. This technique is based on the fact that the oligomeric products of chitinases and cellulases can be modified by chitooligosaccharide oxidase (ChitO) and the mutant ChitO ChitO-Q268R, respectively, producing hydrogen peroxide $\left(\mathrm{H}_{2} \mathrm{O}_{2}\right)$. The amount of $\mathrm{H}_{2} \mathrm{O}_{2}$ released is then monitored using a second enzyme, horseradish peroxidase, together with a peroxidase substrate [21]. Azo-dyed and azurine cross-linked (AZCL) polysaccharides are also very widely used for GH screening in a variety of assay types [22,23]. AZCL substrates are produced by cross-linking polysaccharides to render them insoluble and then dyeing them. When exposed to an enzyme with appropriate activity, small dyed oligosaccharide products are released [24]. Assays can be performed in multi-well (usually 96) plates, and activity is detected by the change in colour of enzyme reaction supernatants which can be measured spectrophotometrically. Alternatively, AZCL substrates can be incorporated into agar plates, and activity can be monitored by the formation of coloured halos as the dyed oligosaccharides diffuse into the gel. AZCL-based assays have found widespread usage because of their speed, ease of use and relatively low cost, but they do have some disadvantages, especially in microplate assays [25]. The substrates are only available in one colour (dark blue), limiting throughput since only one substrate can be tested per reaction. Also, they are powders which must be individually weighed into the wells of multi-well plates and undigested substrate particles can interfere with subsequent measurement of coloured supernatants.

We have developed a new generation of chromogenic polysaccharide hydrogel $(\mathrm{CPH})$ substrates based on chlorotriazine dyes that, when used in conjunction with a 96-well filter plate, form a high-throughput assay system. Each substrate can be produced in one of the four colours, and different coloured substrates can be combined in a single well. The use of dyed insoluble polysaccharide substrates has been known for some time, such as in agar plates [26-28] and use of dyed cellulose and starch [29] derivatives. This type of substrates has been used in agar plates [30,31], and this is the first time that a high-throughput assay such as the one we describe has been developed and established. We show here that this methodology can be applied to a wide variety of polysaccharides and proteins and demonstrate its potential for screening GHs, LPMOs and proteases. Importantly, we have also produced chlorotriazine-dyed biomass samples which provide information about substrate availability within the complex polymer mixtures typically encountered by enzymes in industrial contexts.

\section{Results and discussion}

\section{Development of novel chromogenic hydrogel substrates}

$\mathrm{CPH}$ substrates were produced by first dyeing polysaccharides with one of the four chlorotriazine dyes (red, blue, green or yellow) via nucleophilic aromatic substitution $\left(\mathrm{S}_{\mathrm{N}} \mathrm{Ar}\right)$ [32]. The polysaccharides were then cross-linked with 1,4-butanediol diglycidyl ether via base-catalysed epoxide opening. The resulting materials are hydrogels which can be easily dispensed using syringes into 96-well filter plates (Figure 1A,B) and be stored for at least 24 months at $4^{\circ} \mathrm{C}$ without loss of function. A list of the $\mathrm{CPH}$ substrates made to date is shown in Table 1 , and the enzymes used to test them are detailed in Table 2.

We developed a rapid assay using the $\mathrm{CPH}$ substrates based on 96-well filter plates. Solutions containing enzymes or appropriate buffer controls are added to the wells containing $\mathrm{CPH}$ substrates to form the 'reaction plate' (Figure 1C). The plate is then sealed and incubated under the desired conditions (Figure 1D). If an enzyme is active against a particular substrate, then soluble, dyed oligosaccharide products are released (some undigested insoluble substrate may remain). The reaction plate is then placed on top of an ordinary 96-well plate (the 'product plate'), and the two plates are either centrifuged together or placed in a 96-well plate vacuum manifold so that the liquid phase in the reaction plate is transferred through the filter in the bottom to the product plate below (Figure 1E). The absorbance of the products is then measured using a multi-well plate spectrophotometer. The fact that each $\mathrm{CPH}$ substrate can be made in four colours may be exploited to increase the throughput of the technique since multiple substrates can be present in a single well. In a theoretical example shown in Figure 1F, a blue CPH-galactomannan and yellow $\mathrm{CPH}$-xylan substrate are combined in each well, so that mannanase and xylanase activities are detected by the release of blue and yellow products, respectively. If both activities are present then a green product is produced. This general approach can be extended so that up to four substrates are combined.

The soluble products (examples of which are shown in Figure 2A) have distinct spectral properties, and examples of spectral scans of products from red, blue, green and yellow CPH-2-hydroxyethyl-cellulose (CPH-HE cellulose) 


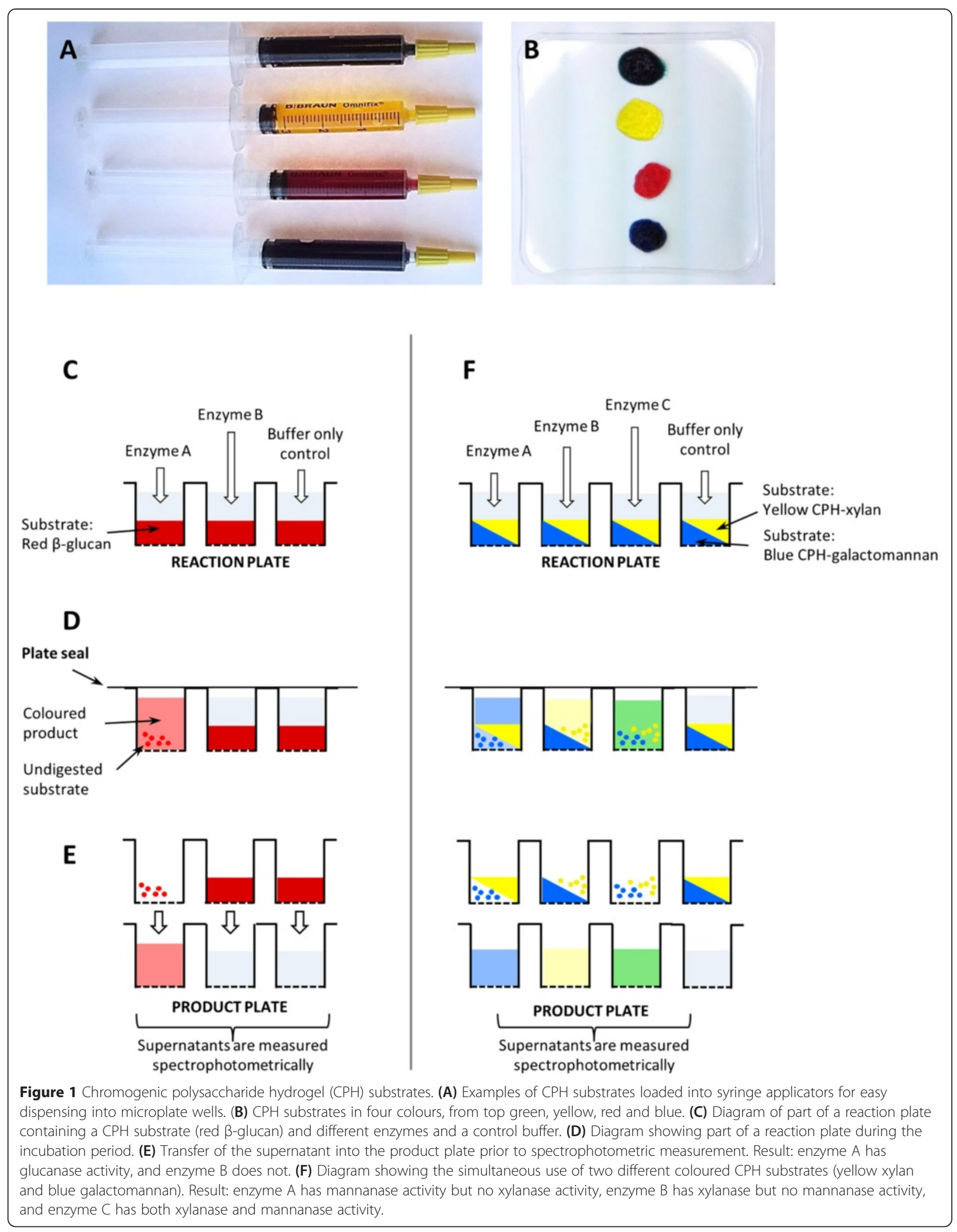


Table 1 List of CPH substrates made and used in the study along with substrate sources

\begin{tabular}{|c|c|}
\hline Substrate & Source \\
\hline $\begin{array}{l}\text { CPH-2-hydroxyethylcellulose } \\
\text { (CPH-HE cellulose) }\end{array}$ & $\mathrm{N} / \mathrm{A}$ \\
\hline $\mathrm{CPH}$-amylopectin & Potato \\
\hline $\mathrm{CPH}$-amylose & Potato \\
\hline $\mathrm{CPH}$-arabinan & Sugar beet \\
\hline $\mathrm{CPH}$-arabinoxylan & Wheat \\
\hline $\mathrm{CPH}$-casein & Bovine milk \\
\hline $\mathrm{CPH}$-curdlan & Alcaligenes faecalis \\
\hline $\mathrm{CPH}$-dextran & Leuconostoc spp. \\
\hline $\mathrm{CPH}$-galactomannan & Carob \\
\hline $\mathrm{CPH}$-laminarin & Laminaria digitata \\
\hline CPH-lichenan & Icelandic moss \\
\hline CPH-pachyman & Poria cocos \\
\hline CPH-pectic galactan & Potato \\
\hline CPH-pullulan & Aureobasidium pullulans \\
\hline CPH-rhamnogalacturonan I & Potato \\
\hline $\begin{array}{l}\text { CPH-rhamnogalacturonan I } \\
(- \text { Gal })^{\mathrm{a}}\end{array}$ & Potato \\
\hline $\mathrm{CPH}$-rhamnogalacturonan & Soy bean \\
\hline $\mathrm{CPH}-\mathrm{xylan}$ & Beechwood \\
\hline CPH-xyloglucan & Tamarind \\
\hline $\mathrm{CPH}-\beta$-glucan from barley & Barley \\
\hline $\mathrm{CPH}-\beta$-glucan from oat & Oat \\
\hline $\mathrm{CPH}-\beta$-glucan from yeast & Yeast \\
\hline ICB-Arabidopsis & $\begin{array}{l}\text { Rosette leaves from Arabidopsis } \\
\text { thaliana Col-0 (adult plant) }\end{array}$ \\
\hline ICB-bagasse & $\begin{array}{l}\text { Saccharum officinarum } \\
\text { (dried adult plant, stem and leaves) }\end{array}$ \\
\hline ICB-fenugreek seeds & Trigonella spp. seeds \\
\hline ICB-hemp & $\begin{array}{l}\text { Cannabis spp. (dried adult plant, } \\
\text { stem and leaves) }\end{array}$ \\
\hline ICB-lupin seeds & Lupinus angustifolius seeds \\
\hline ICB-lupin seeds & Lupinus angustifolius seeds \\
\hline ICB-tobacco & $\begin{array}{l}\text { Leaves from Nicotiana benthamiana } \\
\text { (young plant) }\end{array}$ \\
\hline ICB-wheat straw & $\begin{array}{l}\text { Triticum spp. (dried adult plant, } \\
\text { stem and leaves) }\end{array}$ \\
\hline ICB-willow & Salix spp. (dried adult plant, milled \\
\hline
\end{tabular}

${ }^{a}(\beta-1,4-D-g a l a c t a n$ side chains removed with endo-galactanase gal). N/A, not applicable.

digested with an endo-cellulase (cel1) are shown in Figure 2B. For comparison, the spectrum of products released by digestion of AZCL-HE cellulose with the same enzyme is also shown in Figure 2B. When different coloured substrates are combined in a single reaction with more than one enzyme, then the colour of the products reflects the relative activities of the enzyme mixture against each substrate. Examples of the products of mixed substrates are shown in Figure 2C,D and demonstrate that increments of $10 \%$ in colour contribution can be clearly resolved by visual inspection of the products and by differences in the spectra. Linear regression analysis showed that when two substrates with different dyes were present in known ratios in the range from 9:1 to 1:9, this ratio could be estimated within $\pm 5 \%$ of the true value based on visible light absorbance spectra of the unmixed coloured supernatants and the spectrum recorded for the mixture. This was done for all two-colour combinations (Additional file 1: Figure S1).

\section{Stability, reproducibility, detection limits and dose response}

The reproducibility of the $\mathrm{CPH}$ substrate assays was tested by setting up a series of replicate reactions and measuring the variability of the products (Additional file 2: Figure S2). A series of substrates was made in various colours and added in sextuplet to wells in a 96-well reaction plate. Enzymes were added, and after 30-min incubation, the products were collected and quantified at the appropriate wavelength for each colour (Additional file 2: Figure S2A). This procedure was repeated three more times, so that variability both with single plates and across plates was assessed. The quantified products from these experiments (Additional file 2: Figure S2B) are shown in Additional file 2: Figure S2C and demonstrate a high degree of reproducibility (with a standard error of mean (SEM) no greater than $7 \%$ ). We also tested dose response by varying both enzyme concentration and reaction time (Figure 3). The effect of enzyme concentration is shown for four differently coloured versions of the $\mathrm{CPH}$-galactomannan substrate treated for $1 \mathrm{~h}$ with mannanase (man) used between 0 and $2 \mathrm{U} / \mathrm{mL}$ (Figure 3A,B). The increased colour production can be clearly seen in the product plate (Figure $3 \mathrm{~B}$ ) and quantification of the products revealed that although the absolute absorbance values were different, each substrate yielded an essentially linear response with increasing enzyme concentration (Figure 3C). The release of products over time was assessed by making four different coloured versions of $\mathrm{CPH}$-xyloglucan, digesting with xyloglucanase $x g$ at $0.25 \mathrm{U} / \mathrm{mL}$ and measuring the absorbances of products formed in 20-min intervals (Figure 3D). In parallel, we also set up the same reaction with undyed xyloglucan and measured the release of reducing ends using the MBTH referred to previously (black line in Figure 3D). Absorbance values were measured at the appropriate wavelengths for each substrate, and again, although the absolute absorbance values varied between the differently coloured versions of the substrate, the trend was the same for each, and this trend closely followed the production of reducing ends from the undyed xyloglucan. The detection 
Table 2 Enzymes used in the study

\begin{tabular}{|c|c|c|c|}
\hline Code name & Description & CAZy family & Source \\
\hline ara & Endo-arabinase (Aspergillus niger) & $\mathrm{GH} 43$ & Megazyme \\
\hline cell & Endo-cellulase (endo- $\beta-1,4-g l u c a n a s e)$ (Trichoderma longibrachiatum) & $\mathrm{GH} 7$ & Megazyme \\
\hline cel2 & Cellulase (endo- $\beta-1,4-$ glucanase) (Bacillus amyloliquefaciens) & GH5 & Megazyme \\
\hline Gal & Endo- $\beta$-1,4-D-galactanase (Aspergillus niger) & GH53 & Megazyme \\
\hline$g / c$ & Endo- $\beta$-1,3-glucanase (Trichoderma sp.) & $\mathrm{GH} 16$ & Megazyme \\
\hline lic & Lichenase (endo- $\beta$-1,3(4)-glucanase) (Bacillius sp.) & $\mathrm{GH} 16$ & Megazyme \\
\hline man & Endo- $\beta-1,4-m a n n a n a s e$ (Cellvibrio japonicus) & $\mathrm{GH} 26$ & Megazyme \\
\hline$n z 1$ & Endo- $\beta-1,4-x y l a n a s e$ (Aspergillus aculeatus) & $\mathrm{GH} 10$ & Novozymes \\
\hline$n z 2$ & Endo- $\beta-1,4-x y l a n a s e$ (Thermomyces lanuginosus) & $\mathrm{GH} 11$ & Novozymes \\
\hline$n z 3$ & Endo- $\beta-1,4$-glucanase (Aspergillus aculeatus) & GH5 & Novozymes \\
\hline$n z 4$ & Proprietary fungal endo- $\beta-1,4-$ mannanase & GH5 & Novozymes \\
\hline ply 1 & Macerase ${ }^{\text {TM }}$ Pectinase (Rhizopus sp.) & N/A & Calbiochem \\
\hline ply2 & Pectolyase Y-23 (Aspergillus japonicus) & N/A & Duchefa Biochemie \\
\hline ply3 & Pectolyase (Aspergillus japonicus) & N/A & Sigma \\
\hline pec1 & Pectate lyase (Cellvibrio japonicus) & PL10 & Megazyme \\
\hline pec2 & Pectate lyase (Aspergillus sp.) & N/A & Megazyme \\
\hline pol1 & Endo-polygalacturonase M2 (Aspergillus niger) & $\mathrm{GH} 28$ & Megazyme \\
\hline pol2 & Endo-polygalacturonase M1 (Aspergillus niger) & $\mathrm{GH} 28$ & Megazyme \\
\hline rgh & Rhamnogalacturonan hydrolase (Aspergillus aculeatus) & $\mathrm{GH} 28$ & Novozymes \\
\hline$x g$ & Xyloglucanase (Paenibacillus sp.) & GH5 & Megazyme \\
\hline$x y / 1$ & $\beta$-xylanase, M4 (Aspergillus niger) & $\mathrm{GH} 11$ & Megazyme \\
\hline$x y / 2$ & Endo- $\beta-1,4$-xylanase M1 (Trichoderma viride) & $\mathrm{GH} 11$ & Megazyme \\
\hline NCLPMO9C & Lytic polysaccharide monoxygenase (Neurospora crassa) & AA9 & N/A \\
\hline Broth & Culture broth from Phanerochaete chrysosporium (3d after inoculation) & N/A & N/A \\
\hline Proteinase $\mathrm{K}$ & Proteinase K (Tritirachium album) & N/A & Sigma \\
\hline Trypsin & Trypsin from bovine pancreas & N/A & Sigma \\
\hline Elastase & Elastase from porcine pancreas & N/A & Sigma \\
\hline
\end{tabular}

Code, source and carbohydrate-active enzyme (CAZy) database family. N/A, not applicable.

limit of the substrates is between 100 and $500(\mathrm{mU} / \mathrm{mL}) / \mathrm{h}$ depending on the substrate and the specific activity of the enzymes.

Most of the enzymes used in the work described here are well-characterized and commercially available (described in Table 2), and data from $\mathrm{CPH}$ substrates was in good agreement with previous findings. However, we also validated the technique by making a direct comparison between the performance of the $\mathrm{CPH}$ substrates and activity data determined by the PAHBAH method to measure the release of reducing ends [17] (Figure 4). Four purified enzymes were tested: two xylanases, a glucanase and a mannanase (designated $n z 1, n z 2, n z 3$ and $n z 4$, respectively) on $\mathrm{CPH}$ substrates of blue $\mathrm{CPH}$ arabinoxylan, yellow $\mathrm{CPH}$-xylan, red $\mathrm{CPH}-\beta$-glucan and green $\mathrm{CPH}$-galactomannan as shown in Figure 4A. Product plate results (Figure 4B) showed that $n z 1$ and $n z 2$ had activity against both $\mathrm{CPH}$-arabinoxylan and $\mathrm{CPH}$-xylan with visibly greater colour production for $n z 2$ against both substrates, and neither enzyme appeared to have activity against $\mathrm{CPH}-\beta$-glucan or $\mathrm{CPH}$-galactomannan. $n z 3$ and $n z 4$ had activity against $\mathrm{CPH}-\beta$-glucan and $\mathrm{CPH}-$ galactomannan, respectively, with no or very little side activity observable. The information about relative activity obtained on the release of reducing ends using the same enzymes with pure (undyed, non-cross-linked) polysaccharides (Figure 4C) was in close agreement with the findings from the $\mathrm{CPH}$ substrates with the same major activities detected and very low side activities (Figure 4C).

To verify that the substrates can perform within a wide range of $\mathrm{pH}$ values, $\mathrm{CPH}-\mathrm{HE}$ cellulose and $\mathrm{CPH}$ rhamnogalacturonan were treated with a cellulase (cel2) and a pectinase (pec1) with activity optima at acidic and basic $\mathrm{pH}$ values, respectively. From this experiment, it was apparent that at least for these substrates, the $\mathrm{CPH}$ polysaccharides are compatible with a wide range of $\mathrm{pH}$ 


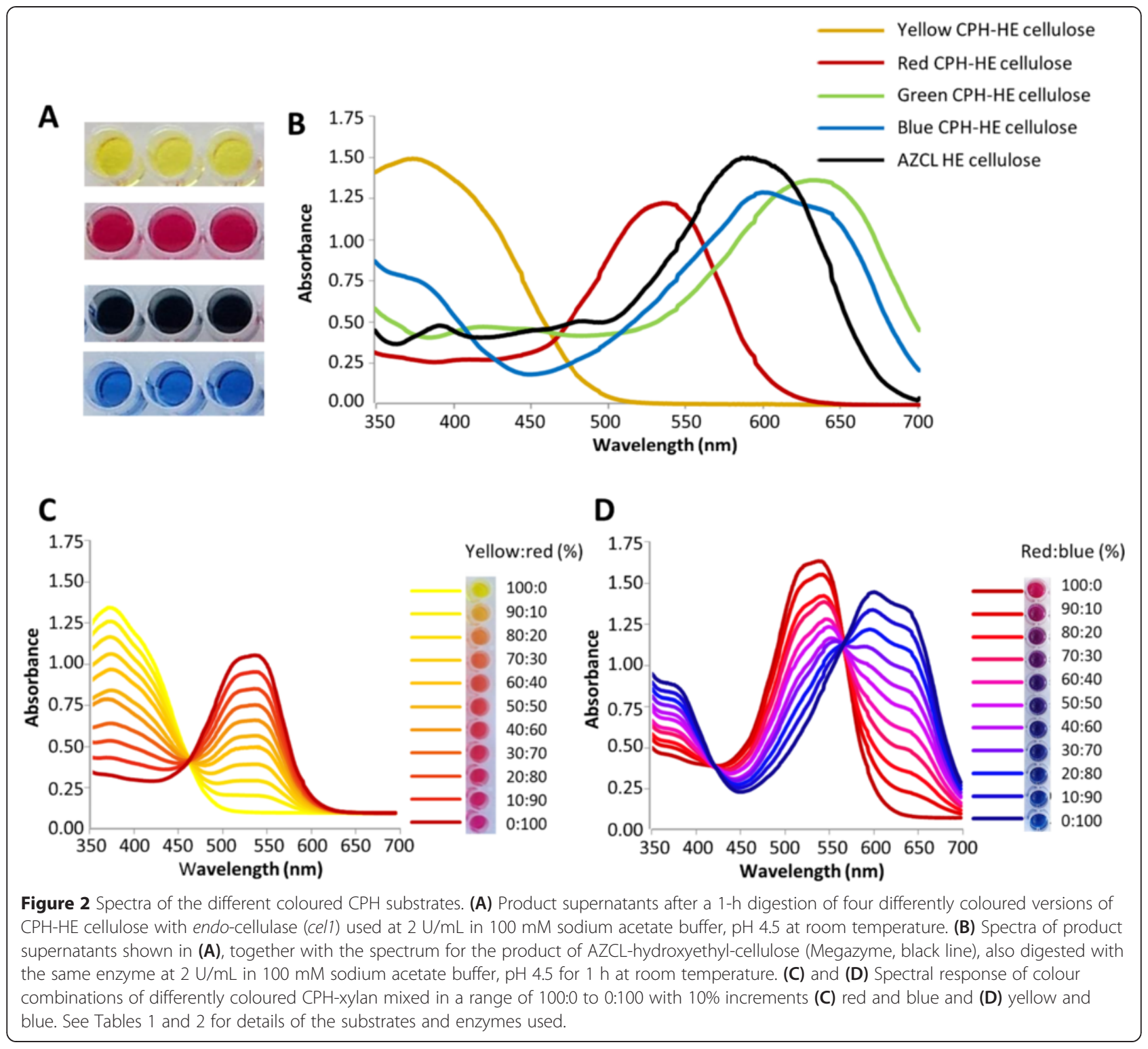

conditions (Additional file 3: Figure S3A). Thermostability of the substrates was tested with $\mathrm{CPH}$-xylan and a thermophilic xylanase ( $x y l 3)$ showing the stability of $\mathrm{CPH}$ substrates at high temperatures (Additional file 3: Figure S3B).

We were interested to assess in detail the nature of the products released from $\mathrm{CPH}$ substrates. To do this, we used matrix-assisted laser desorption/ionizationtime-of-flight-mass spectrometry (MALDI-ToF-MS) to analyse products resulting from the digestion of $\mathrm{CPH}-$ xylan (Additional file 4: Figure S4A) and undyed crosslinked xylan (Additional file 4: Figure S4B) with xylanase xyl1. The spectrum from the CPH-xylan substrate displayed more near-baseline noise than that of the undyed substrate, and this was presumably due to the presence of the dye molecules. However, in both cases, a range of pentose-containing oligosaccharide products were released that were consistent with xylan fragments. From the mass profiles, we determined that in many cases, xylan oligomers were attached to one or more hydrolysed linker molecules, implying that a significant proportion of the linker was not in fact spanning between polysaccharide chains in either the dyed or undyed version of these substrates (shown schematically in Additional file 4: Figure S4C). Despite this apparent incomplete crosslinking, the substrates were still insoluble and still effective substrates for $x y l 1$.

We also tested the storage stability of $\mathrm{CPH}$ substrates. A set of reaction plates was made, sealed and stored at $4^{\circ} \mathrm{C}$ for 1 year. A series of enzyme digestions were made on these plates and compared to identical reactions made in freshly produced reaction plates. As shown in 


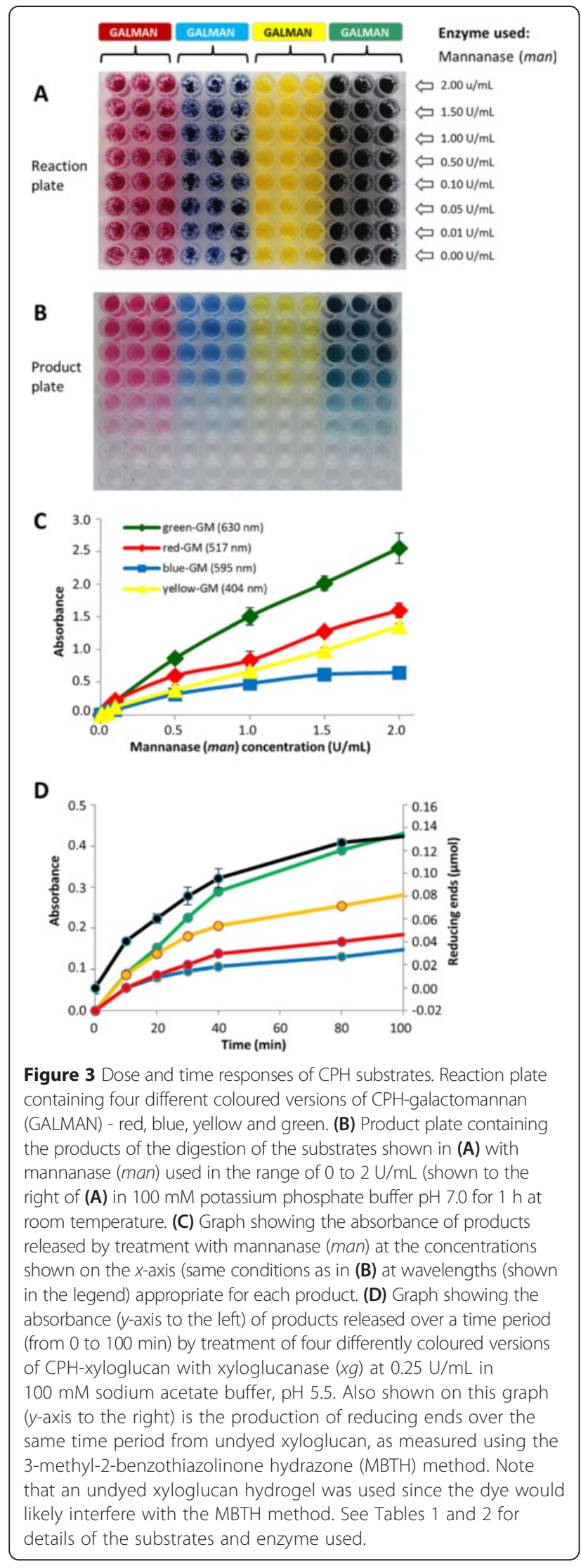

Additional file 5: Figure S5, there was high degree of consistency between the fresh and stored plates.

Taken together, these data indicate that the assays based on $\mathrm{CPH}$ substrates are reproducible, stable over time and can tolerate a range of $\mathrm{pH}$ and temperature conditions. Like all chromogenic substrates, the $\mathrm{CPH}$ polysaccharides are intended for semi-quantitative analysis, but nevertheless, the $\mathrm{CPH}$ dose-response profiles show that, for at least the examples tested, the amount of coloured products produced is proportional to the amount of enzyme present and/or incubation times. Moreover, our results from MALDI-ToF analysis suggest that the dying process does not fundamentally alter the nature of the products released.

\section{Multiplexed assays using mixtures of enzymes and substrates}

The ability to produce $\mathrm{CPH}$ substrates in four different colours is an important feature that can be used to increase the throughput of $\mathrm{CPH}$ substrate assays. An example of an assay involving multiple mixed substrates and enzymes is shown in Figure 5 . Red $\mathrm{CPH}-\beta$-glucan, yellow $\mathrm{CPH}$-xylan, green $\mathrm{CPH}$-galactomannan and blue $\mathrm{CPH}$-arabinoxylan were added to wells either alone or mixtures of two, three or four substrates together in the same well (Figure 5A). The $n z$ series of enzymes previously characterized (see Figure 4) were added to wells alone or as mixtures of two or three enzymes (Figure 5A). The resulting product plate from these reactions is shown in Figure 5B. Single enzymes acting on single substrates produced the expected corresponding colour of product but importantly, individual enzyme activities could be resolved by their coloured products even when multiple substrates were present. For example, the product of well A5 had the qualitatively same spectral response as the products in wells $\mathrm{B} 5$ and $\mathrm{D} 5$, despite the fact that whereas in A5, only red $\mathrm{CPH}-\beta$-glucan was present, in B5 and D5, the red $\mathrm{CPH}-\beta$-glucan was mixed with one and three other substrates, respectively (Figure 5C). A similar effect was observed for wells A11, B11 and D11 which produced essentially qualitatively the same spectral responses of a green product, although only well A11 of the substrate plate contained green galactomannan alone (Figure 5D). Note that there are quantitative differences in the absorbance values, and these reflect the fact that when substrates mixed in a single well, then the amount of each individual substrate is proportionally lower since the total volume of substrate material is the same in each well. Thus, the absorbance value for products from well D11 is lower than for well A11 because in D11, the green galactomannan was combined with three other substrates (Figure 5D).

Substrate mixtures also enable multiple enzyme activities to be detected simultaneously. For example, wells G4, G6 and G12 of the substrate plate all contained the 


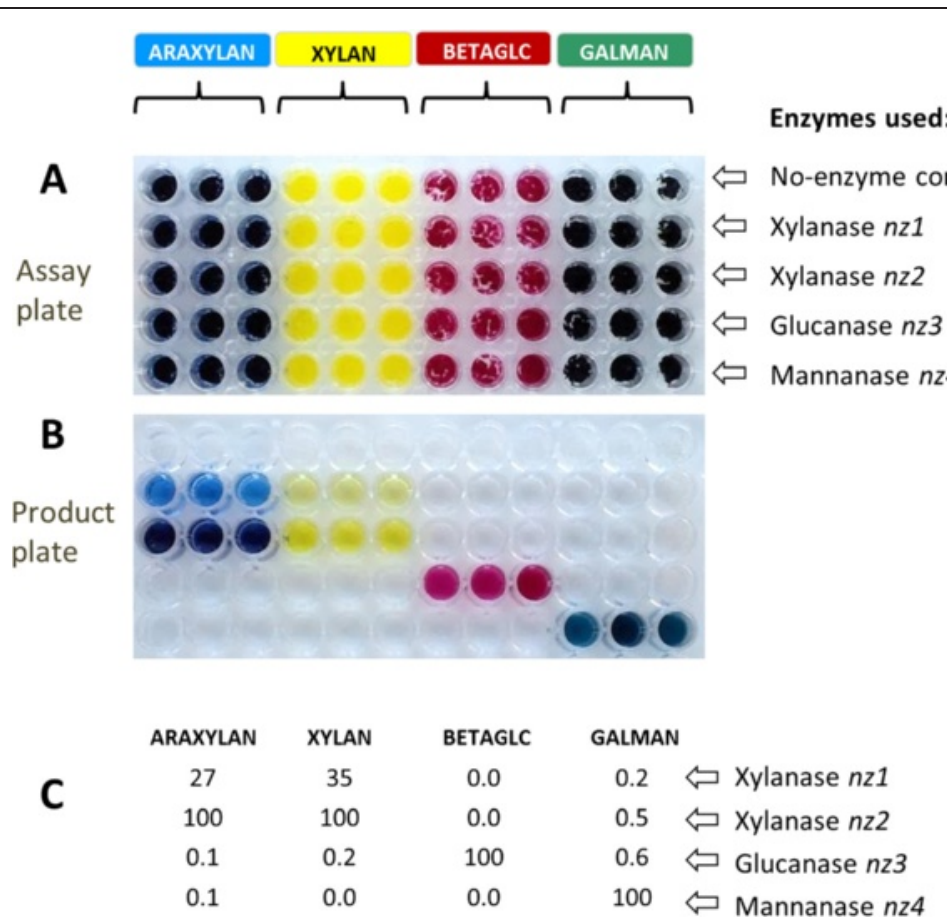

Figure 4 Direct comparison of the output from $\mathrm{CPH}$ substrates with the measurement of reducing ends. (A) Each well in the reaction plate contained one of the four different CPH substrates: blue CPH-arabinoxylan (ARAXYLAN); yellow CPH-xylan, (XYLAN); red CPH- $\beta$-glucan (BETAGLC) and green CPH-galactomannan (GALMAN). The substrates were treated with the enzymes: xylanase $n z 1$; xylanase $n z 2 ;$ glucanase $n z 3$ or mannanase (nz4) as shown to the right (note that all wells in one row contained the enzymes or control buffer indicted). All enzymes were used at $5 \mu \mathrm{g} / \mathrm{mL}$ in $50 \mathrm{mM} \mathrm{sodium}$ acetate buffer, pH 5.5 and incubated at $50^{\circ} \mathrm{C}$ for $10 \mathrm{~min}$. (B) Product plate containing the product of the reaction shown in (A). (C) Table showing the relative activities of the enzymes $n z 1$ to $n z 4$ as determined by the production of reducing ends when native versions of the polysaccharides shown in (A) were treated with enzymes $n z 1$ to $n z 4$ used at $5 \mu \mathrm{g} / \mathrm{mL}$ in $50 \mathrm{mM}$ sodium acetate buffer, pH 5.5 at $50^{\circ} \mathrm{C}$ for $10 \mathrm{~min}$. The highest value was set to 100, and all other values adjusted accordingly. In this case, the PAHBAH reducing end assay was used. See Tables 1 and 2 for details of the substrates and enzyme used.

same mixture of yellow xylan, green galactomannan and red $\beta$-glucan. When xylanase $n z 1$ alone was added (well G4), then the expected yellow product was produced, but the contribution of both glucanase $n z 3$ and xylanase $n z 1$ (well G6) are apparent by the orange product with its distinct spectral response. When mannanase $n z 4$ was also added (well G12), the contribution of the green product can also be detected by a distinct spectrum (Figure 5E).

\section{Detecting enzymatic activities in microbial broths}

We also tested the utility of the $\mathrm{CPH}$ substrates for assessing enzymatic activity in broths of Penicillium expansum and Colletotrichum acutatum cultured on apple pomace liquid media (Additional file 6: Figure S6). Samples of the crude broths were taken once daily from 1 to 10 days after inoculation. The broths were applied directly to 96-well assay plates containing a variety of $\mathrm{CPH}$ substrates including $\mathrm{CPH}$-galactomannan (Additional file 6: Figure S6A), $\mathrm{CPH}$-lichenan, $\mathrm{CPH}-\beta$-glucan from barley (Additional file 6: Figure $\mathrm{S} 6 \mathrm{~B}$ and $\mathrm{S} 6 \mathrm{C}$, respectively) and arabinoxylan (Additional file 6: Figure S6D). As expected, broths from both fungi showed a general increase over time in their ability to degrade the substrates, but there were striking differences in the relative activities produced by the two species. After 3 days, there was a sharp increase in mannanase activity in the $C$. acutatum broth (Additional file 6: Figure S6A), whereas the $P$. expansum broth had notably increased activity against lichenan and $\beta-(1,3),(1-4)$-glucan from barley (Additional file 6: Figure S6B and S6C). The degradation results for arabinoxylan were similar for both fungi (Additional file 6: Figure S6D).

\section{CPH substrates can also be used in a simple agar gel system}

We considered that for some applications, it might be preferable to use a very simple gel-based assay in which enzyme activity is detected by the formation of a coloured halo (Figure 6). This approach is conceptually similar to assays in which particulate AZCL substrates are embedded within agar. Our method differs in that instead of being distributed through the agar, the $\mathrm{CPH}$ substrates are contained within a well, either made at the casting stage or subsequently once the agar has set 





(See figure on previous page.)

Figure 5 Multiplexed assays using the CPH substrates in different substrate and enzyme concentrations. (A) Setup of the reaction plate: $\mathrm{CPH}$ substrates used in the experiment were red $\mathrm{CPH}$ - $\beta$-glucan, green $\mathrm{CPH}$-galactomannan, yellow $\mathrm{CPH}$-xylan and blue $\mathrm{CPH}$-arabinoxylan, and the distribution of these substrates within the reaction plate is shown to the left. Each well contained a single substrate or two, three or four substrates mixed together. Note that the total volume of substrate was the same in each well, and when substrates were mixed in wells, they were present in equal amounts. The distribution of enzymes in the reaction plate is shown to the right, and the enzymes used were xylanase $n z 1$, xylanase $n z 2$, glucanase $n z 3$ and mannanase $n z 4$. Note that the total amount of enzyme was the same in each well, and when enzymes were mixed in wells, they were present in equal amounts. Some wells contain buffer only ('Neg'). The reaction buffer used was $50 \mathrm{mM}$ sodium acetate buffer, pH 5.5. (B) Image of the product plate containing the products of the reactions shown in (A) after a 10-min reaction at $50^{\circ} \mathrm{C}$. (C) to (E) spectra of selected wells as shown in the legends. See Tables 1 and 2 for details of the substrates and enzyme used.

(Figure 6A). If an enzyme has activity against the $\mathrm{CPH}$ substrate, then small, soluble products are released that diffuse through the agar and are seen as halos around the wells (Figure 6B). Typically, overnight (18 h) incubations are used, and representative experiments using an endo-glucanase $(g l c)$ and a xyloglucanase $(x g)$ are shown in Figure 6C,D. In these experiments, four differently coloured versions of pachyman (Figure 6C) and xyloglucan (Figure 6D) were made and treated with $g l c$ (see Table 2) and $x g$ (see Table 2), respectively. Halos were generated from each substrate version by the respective enzymes, and not by buffer controls.

Using a similar rationale to that described for multi-well plate-based assays, substrates can also be mixed. In the example shown in Figure 6E, all of the wells were filled with the same mixture of three substrates (red CPH-pachyman, blue $\mathrm{CPH}$-galactomannan and yellow $\mathrm{CPH}$-xylan). However, the colours of the halo produced after $18 \mathrm{~h}$ depend on the enzyme used, and when more than one enzyme was present, intermediate coloured halos were formed. These experiments showed that although simple, the agar plate-based assays using $\mathrm{CPH}$ substrates have the capacity to be highly information-rich.

\section{Analysis of LPMO and protease activities}

We further extended the scope of the $\mathrm{CPH}$ substrates by assessing if they were compatible with classes of degradative enzyme other than glycosyl hydrolases, specifically an LPMO and different proteases (Figure 7). We used NcLPMO9C, an enzyme that is the first LPMO to be described with activity against both cellulosic and hemicellulosic substrates [4]. Consistent with previous findings, NcLPMO9C released products from $\mathrm{CPH}$ substrate versions of $\mathrm{CPH}-\mathrm{HE}$ cellulose and $\mathrm{CPH}$-lichenan, but not $\mathrm{CPH}$-xylan (Figure 7A). The release of products from $\mathrm{CPH}-\mathrm{HE}$ cellulose and $\mathrm{CPH}-$ lichenan was dependent on the presence of the reducing agent ascorbic acid, since assays lacking ascorbic acid yielded no or negligible products. These data indicate that the activity we observed from NcLPMO9C was indeed mediated by an oxidative reaction. The proteases trypsin, elastase and proteinase $\mathrm{K}$ were tested using $\mathrm{CPH}$-casein, and all three enzymes yielded degradation products (Figure 7B).

\section{Insoluble chromogenic biomass substrates}

Enzymes that degrade or modify biomass feedstocks very rarely, if ever, encounter single polysaccharides in isolation. Rather, enzymes usually act upon highly complex mixtures of polysaccharides that are physically intermeshed and sometimes covalently linked. Ideally, assays for screening enzymes intended for biomass deconstruction should reflect this complexity and heterogeneity, and we therefore further extended the concept of chromogenic substrates by producing a series of dyed versions of biomass materials typically used as biofuel/biorefinery feedstocks. Such insoluble chromogenic biomass (ICB) substrates cannot be used to resolve individual enzyme activities since multiple polymers are dyed with the same colour within a single ICB substrate type. However, they can provide information about the ability of an enzyme, cocktail or microbial broth to release oligomeric products from a complex biomass matrix per se and as such are a useful addition to the screening toolbox.

ICB substrates are based on raw biomass samples or alcohol-insoluble residue (AIR) preparations which are standard crude preparations of polysaccharides widely used as the starting point for biomass analysis, for example, saccharification assays $[33,34]$. As a proof of concept, we made six ICB substrates of vegetative material from Arabidopsis, tobacco, hemp, willow, wheat straw and bagasse. We also made a further two ICB substrates from fenugreek and lupin seeds (the sources of biomass samples are listed in Table 1). This set of samples was chosen because they represent distinct cell wall types with different polymer compositions and architectures. The Arabidopsis and tobacco samples were made from leaf and stem material that is rich in the 'type I' primary cell walls found in the younger green parts of the eudicot species. The wheat and bagasse samples predominantly contain the 'type II' cell walls typical of commelinid monocots in which $\beta$-(1,3),(1,4)-D-glucan and glucuronoarabinoxylans (GAXs) are the prominent hemicelluloses with generally lower levels of pectin. The hemp and willow samples were prepared from older mature organs, which are characterized by secondary cell walls which contain proportionally higher levels of cellulose and xylan than primary cell walls. The lupin and fenugreek seeds are dominated by storage polysaccharides, 

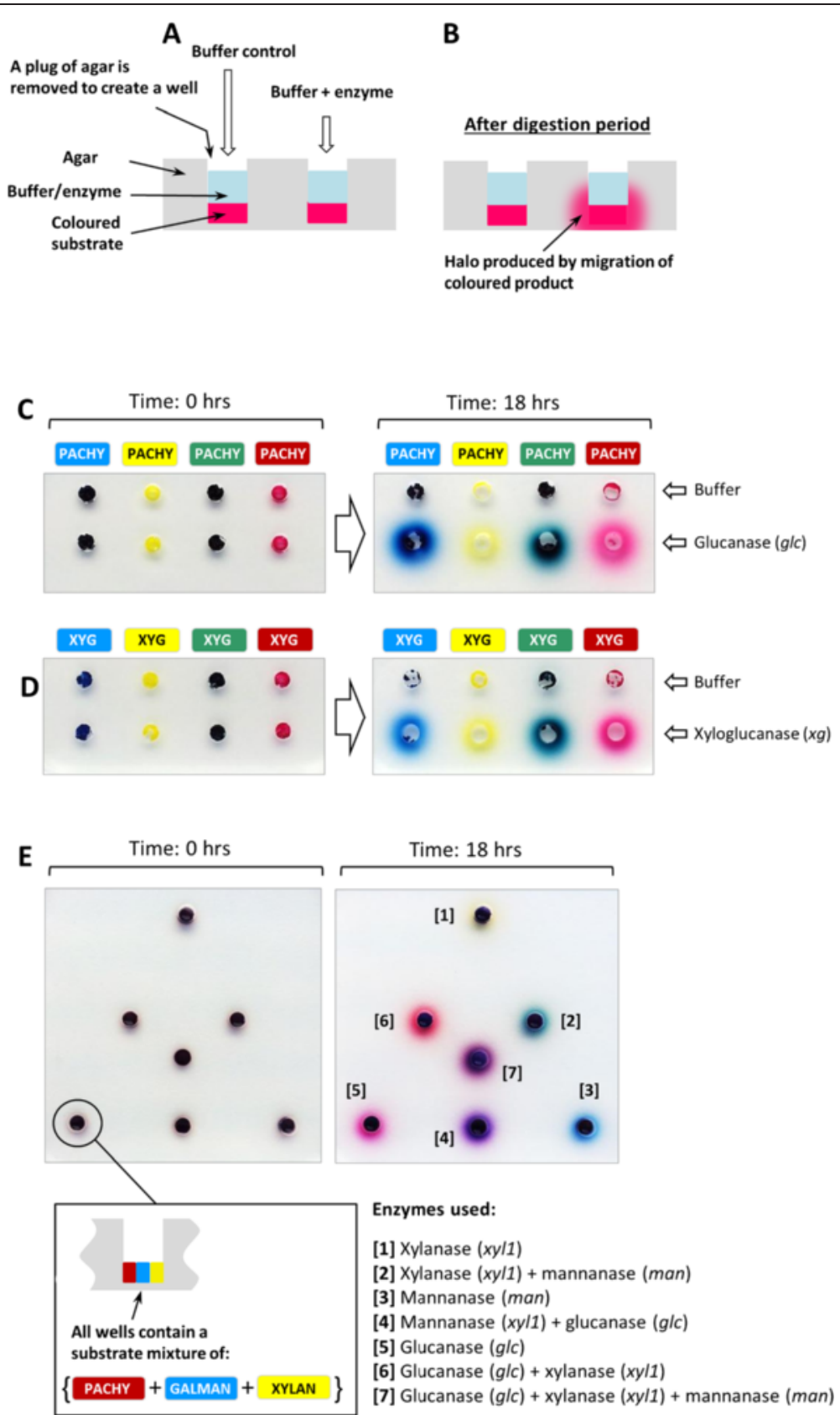

Figure 6 Using CPH substrates in simple agarose plate assays. (A) Schematic illustration of the assay using agarose plates. A well is formed in the agarose (either during or after casting), and CPH substrate is added together with an enzyme-containing solution. (B) Diagram showing the situation after the digestion period. If the enzyme has activity against the CPH substrate, then a halo is formed by the migration of soluble products. (C) and (D) examples of agarose plate assays with a glucanase ( $\mathrm{g} / \mathrm{c}$ ) used to digest four differently coloured version of CPH-pachyman (PACHY), and a xyloglucanase (xg) used to digest four differently coloured versions of $\mathrm{CPH}$-xyloglucan (XYG), respectively. (E) An example of an agar plate assay containing mixed $\mathrm{CPH}$ substrates. All the wells contained red CPH-pachyman (PACHY), blue CPH-galactomannan (GALMAN) and yellow CPH-xylan (XYLAN) mixed in approximately equal proportions. Note that different coloured halos are generated depending on what enzyme or combinations of enzymes were present in wells and as indicated in the legend. See Tables 1 and 2 for details of the substrates and enzyme used.

and lupin seeds are distinctive because $\beta$-(1,4)-D-galactan is highly abundant.

The eight ICB substrates were treated separately with a range of enzymes, and the resulting products quantified (Additional file 7: Figure S7). The overall product profiles for Arabidopsis and tobacco material were similar, with relatively high signals obtained for pectinolytic enzymes (ply2 and ply3) (Additional file 7: Figures S7A and S7B). Some activity was also observed for xyloglucanase $(x g)$ and cellulases (cel1 and cel2), and these data 

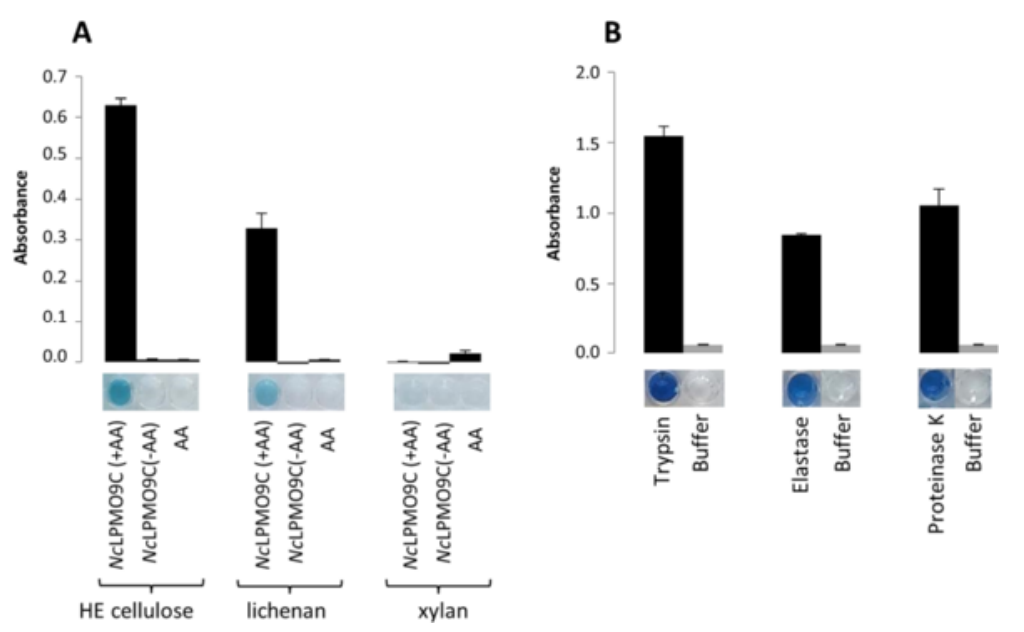

Figure 7 Using CPH substrates to analyse LPMO and protease activities. (A) The LPMO NCLPMO9C was tested using three different CPH substrates, from left to right; blue CPH-HE cellulose; blue CPH-lichenan and blue CPH-xylan. NCLPMO9C was tested with and without ascorbic acid ( $\mathrm{AA}$, used at $3.2 \mathrm{mM}$ ), and ascorbic acid alone was used as a control. Note that activity was observed for the two $\mathrm{CPH}$ substrate that contained $\beta$-linked glucan (blue CPH-HE cellulose; blue CPH-lichenan) but not blue $\mathrm{CPH}$-xylan. All incubations were in $100 \mathrm{mM}$ potassium phosphate buffer, $\mathrm{pH} 7.0$ incubated for $1 \mathrm{~h}$ at $50^{\circ} \mathrm{C}$. (B) Blue $\mathrm{CPH}$-casein was treated with $0.1 \mathrm{U} / \mathrm{mL}$ trypsin, elastase and proteinase $\mathrm{K}$ (containing $10 \mathrm{mM} \mathrm{Ca}{ }^{2+}$ ) in $100 \mathrm{mM}$ sodium phosphate $\mathrm{pH} 7.0$ for $20 \mathrm{~min}$ at room temperature. See Tables 1 and 2 for details of the substrates and enzyme used.

broadly reflect, at least in qualitative terms, the composition of type I primary cell walls. The product profiles from the two commelinid monocot species, wheat and bagasse, were also similar to each other (Additional file 7: Figures S7C and S7D). Compared to Arabidopsis and tobacco, much higher signals were obtained by xylanase (xyl1 and xyl2) treatment and this is consistent with the high levels of GAXs in type II cell walls. Interestingly, although the type II cell walls of grasses contain low levels of pectin, higher signals were obtained with the pectolyases ply 2 and ply 3 than for Arabidopsis and tobacco. One possible explanation for this is that the signals obtained from ICB substrates are a function of both substrate abundance and accessibility and certain pectins may be less abundant but more accessible in type II cell walls compared to their type I counterparts. Relatively high signals were obtained for hemp and willow (Additional file 7: Figures S7E and S7F respectively) from the xylanases xyl1 and $x y l 2$, and this is consistent with the fact that these species contain type II secondary walls. The unusually high level of $\beta$-(1,4)-D-galactan in lupin seeds was readily apparent by comparison of the products produced from the fenugreek and lupin ICB samples (Additional file 7: Figures S7G and S7H, respectively), with abundant product formation by endo- $\beta$-(1-4)-galactanase (gal) digestion of lupin but not fenugreek ICB samples.

We envisage that, when used in combination, the $\mathrm{CPH}$ substrates of defined polysaccharides and ICB substrates can provide insight into what substrate is degraded by an enzyme, to what extent that substrate is available for degradation within a given biomass type. Some caution is required in interpreting data from ICB substrates because we cannot determine to what extent each individual polysaccharide within a biomass sample is dyed, and they are most likely not dyed to an equal extent. Nevertheless, we noted that all the enzymes we used did yield products to some degree, suggesting that most if not all, the polymers were in fact dyed.

We were also interested to analyse what oligomeric products were released from ICB substrates and performed MALDI-ToF-MS analysis of products from hemp and bagasse ICB substrates (Additional file 8: Figure S8A and S8B, respectively) treated with xylanases $x y l 1$ and $n z 2$, respectively. The spectra showed that the enzymes released products similar to those that would be expected for the corresponding natural feedstocks. As expected, xylanases $x y l 1$ release pentose sugars with or without glucuronic acids depending on the feedstock. Xylans in monocotyledons are typified by arabinosyl- and (4-methyl)-glucuronic acid substituents [35], whereas dicot hardwood xylan contains mainly 4-methyl-glucuronic acid substitutions [36]. Both these types of substitutions limit xylanase activity [37], and consistent with this, we observed longer oligosaccharides which would not be expected in linear xylan devoid of substitutions. Another observation from Additional file 8: Figure S8 is that there are no acetyl-ester modifications present which are common on xylan in these materials [38] and that is due to the high $\mathrm{pH}$ used during substrate synthesis which causes hydrolysis of all esters.

\section{Conclusions}

We show here that a new generation of chromogenic substrates have considerable potential for screening single enzymes, enzyme cocktails and microbial broths 
relevant for biomass deconstruction. Several other chromogenic substrate-based assays have been described, but the $\mathrm{CPH}$ and ICB substrates have some distinct features that make them a valuable addition to existing screening technology. Because they are hydrogels rather than powders, the $\mathrm{CPH}$ substrates are convenient to handle and quick and easy to distribute into assay plates. The ability to produce both $\mathrm{CPH}$ and ICB substrates in several colours supports high-throughput multiplexed assays whereby multiple enzymes or side activities of a single enzyme can be detected in a single reaction well. This means that $\mathrm{CPH}$-based assays have the capacity to be highly information-rich compared to other simple assay systems. Furthermore, to our knowledge, the ICB substrates represent the first attempt to produce a rapid assay system in which the natural multipolymer complexity of biofuel feedstocks is represented. Our data also showed that both $\mathrm{CPH}$ and ICB substrates have potential for LPMO and protease screening.

However, in common with other insoluble chromogenic substrates, the $\mathrm{CPH}$ and $\mathrm{ICB}$ reagents also have limitations. For example, ester bonds are not preserved, so esterase activities cannot be tested. Also, as with AZCL polysaccharides, the $\mathrm{CPH}$ and ICB substrates are not reactive with exo-acting enzymes, presumably because of steric hindrance of cleavage sites and alternative methods may need to be employed for assaying that class of GHs. It is also important to recognise that although spectrophotometric analysis of the $\mathrm{CPH}$ and ICB products provides quantitative information about relative activity levels, these assays are not intended to replace fully quantitative biochemical techniques to measure absolute activity values. We envisage that the 96-well assays we have developed will be used primarily for first-level screening of large numbers of putative CAZymes, and the assays have the potential to be incorporated into fully or semi-automated robotic enzyme screening systems.

\section{Methods}

\section{Reagents, enzymes and microorganisms}

Amylose, 2-hydroxyethyl-cellulose (Sigma 434965, molar 2-hydroxyethyl substitution $2.5 \mathrm{~mol}$ per mol cellulose), curdlan, laminarin, amylopectin, pectolyase from $A$. japonicus and $\alpha$-amylase from bovine pancreas were obtained from Sigma (Brøndby, Denmark). All other polysaccharides were obtained from Megazyme (Bray, Ireland). The enzymes used are listed with the supplier in Table 2. The dyes reactive red 4, reactive blue 4, reactive green 19 and reactive yellow 2, cross-linker 1,4-butanediol diglycidyl ether, $\mathrm{NaOH}$ and all salts for buffers were obtained from Sigma (Brøndby, Denmark). Two pathogenic fungi $C$. acutatum (isolate SA 0-1) and $P$. expansum (isolate IK2020) and the apple pomace media were kindly provided by Birgit Jensen and Daniel Buchvaldt Amby (Department of Plant and Environmental Sciences, Faculty of Science, University of Copenhagen, 1871 Frederiksberg, Denmark).

\section{Production of $\mathrm{CPH}$ and ICB substrates}

Synthesis of CPH substrates was performed according to a protocol modified from Ten et al. [30]. The polymer was mixed with $0.5 \mathrm{M} \mathrm{NaOH}$ (concentrations from $3 \%$ to $20 \% w / V)$, and the sample was dissolved by shaking $(110 \mathrm{rpm})$ at $60^{\circ} \mathrm{C}$ (or room temperature). Samples were then dyed by adding $0.5 \mathrm{~g}$ of chlorotriazine dye followed by incubation at $60^{\circ} \mathrm{C}$ (or at room temperature for substrates soluble at room temperature) for 0.5 to $4 \mathrm{~h}$ with shaking. Cross-linking of the dyed polysaccharide solutions was achieved, after being cooled down to room temperature if needed, by adding 1,4-butanediol-diglycidyl ether. The cross-linker concentration ranged from $1.2 \%$ to $16 \%(V / V)$ and was optimized to provide maximum hydrogel responsiveness for enzyme digestion whilst preserving optimal physical consistency for handling and the optimal amount it varied greatly from polysaccharide to polysaccharide. The reaction mixture was vortexed vigorously for $2 \mathrm{~min}$ and then left to stand for 48 to $96 \mathrm{~h}$ at room temperature without agitation for hydrogel formation. To enable more efficient purification and handling, the resulting hydrogels were homogenized within the tube using a spatula to a paste-like material and the material was transferred onto a nylon membrane mesh (31- $\mu$ m mesh) placed over a Büchner funnel where it was washed with boiling sterile water until no more free dye was released, left to stand until there was no more water draining from the funnel, collected into a fresh tube, and stored at $4^{\circ} \mathrm{C}$. In the case of the casein protein substrate, the last wash was with $0.01 \% \mathrm{NaN}_{3}$ in sterile water. Production of ICB substrates was based on the same dyeing chemistry as for the $\mathrm{CPH}$ substrates, but the cross-linking step was omitted. Briefly, $2 \mathrm{~g}$ of plant material (freeze-dried and crushed raw and not pre-treated) and $500 \mathrm{mg}$ of dye were mixed and suspended in 10 to $20 \mathrm{~mL}$ of $0.5 \mathrm{M}$ $\mathrm{NaOH}$ (the volume was adjusted so that the suspension was free-flowing). The reaction mixture was shaken for $4 \mathrm{~h}$ at room temperature. After cooling to room temperature, the substrates were cleaned similarly as for the $\mathrm{CPH}$ substrates above. After an isopropanol wash, samples were stored suspended in isopropanol at $4^{\circ} \mathrm{C}$.

Effects of dye concentration have not been studied in detail, especially because dyes used were of technical grade, but the general observation was that there is no observable change in substrate properties depending upon dye concentration within the concentration range tested ( $5 \%$ to $20 \%, w / V)$. 


\section{Enzyme assay in 96-well filter plates}

Enzyme activity assays in 96-well plate format were performed by transferring $100 \mu \mathrm{L} \mathrm{CPH}$ or $1 \mathrm{mg}$ ICB substrates into a 96-well 'reaction' plate (filter-plate MSHVN4510, Millipore, VWR, Herlev, Denmark) where they were washed once with water. Buffer $(100 \mathrm{mM}$, sodium acetate or potassium phosphate buffer, $\mathrm{pH}$ dependent on the individual enzyme) containing enzyme ( 0.5 to $2 \mathrm{U} / \mathrm{mL}$ ) was added to each well to a final volume of $150 \mu \mathrm{L}$. The plate was sealed using adhesive PCR plate seals (Thermo Scientific, VWR, Herlev, Denmark) and incubated for $10 \mathrm{~min}$ to $1 \mathrm{~h}$ at room temperature with shaking. The reaction plate was then place on top of another 96-well plate (the 'product plate', MSCPNUV40, Millipore, Herlev, Denmark), and supernatants containing products were transferred by centrifugation at 2,700 $g$ for $10 \mathrm{~min}$ or by using a vacuum manifold. Absorbances were measured at the $\lambda_{\max }$ for each substrate colour (404 nm for yellow, $517 \mathrm{~nm}$ for red, $595 \mathrm{~nm}$ for blue and $630 \mathrm{~nm}$ for green) using a plate reader (SpectraMax M5, Molecular Devices, Sunnyvale, USA).

\section{$\mathrm{CPH}$ assays in agar plates}

Agar plates were cast containing $23 \mathrm{mM}$ Britton-Robinson buffer (pH 6.0), $1 \%$ agar and $0.01 \% \mathrm{NaN}_{3}$. Holes were made in the agar with a metal cylinder borer (diameter $6 \mathrm{~mm}$ ). $\mathrm{CPH}$ substrates (prepared as described above) were diluted (300 mg CPH substrate with $500 \mu \mathrm{L}$ water) and homogenized using a sample disruptor (TissueLyser II, Qiagen AB, Sollentuna, Sweden) at $30 \mathrm{~Hz}$ for $15 \mathrm{~min}$ to form a fluidlike gel suspension. Sixty microliters of each substrate was transferred to each hole. The wells were topped with $0.75 \%$ agar. To perform the assay, $20 \mu \mathrm{L} 10 \mathrm{U} / \mathrm{mL}$ of enzyme in appropriate buffer was added and the plate was incubated overnight at $30^{\circ} \mathrm{C}$, after which halos were examined.

\section{Analysis of culture broth from fungi}

Two pathogenic fungi C. acutatum (isolate SA 0-1) and $P$. expansum (isolate IK2020) were cultivated following the protocol described in Vidal-Melgosa et al. 2015 [39]. Supernatants were collected every day, frozen in liquid nitrogen and stored at $-80^{\circ} \mathrm{C}$ until use. To assay enzyme activities in the broths, $5 \mu \mathrm{L}$ of broth was added to $100 \mathrm{mM}$ sodium acetate buffer $\mathrm{pH} 4.5$ to a final volume of $155 \mu \mathrm{L}$. This solution was then used to perform $\mathrm{CPH}$ substrate assays as describe above with an incubation time of $1 \mathrm{~h}$ and at room temperature. Four independent replicates of each sample were performed.

\section{Mass spectrometry}

For mass spectrometry analysis of products, $2 \mu \mathrm{L}$ of a $9 \mathrm{mg} / \mathrm{mL}$ mixture of 2,5-dihydroxybenzoic acid (DHB) in $30 \%$ acetonitrile was applied to a MTP 384 ground steel target plate TF (Bruker Daltonics GmbH, Bremen,
Germany). One-microliter sample was then mixed into the DHB droplet and dried under a stream of air. The samples were analysed with an Ultraflex2 MALDI-ToF/ ToF instrument (Bruker Daltonics GmbH, Bremen, Germany) equipped with a Nitrogen 337-nm laser beam. The instrument was operated in positive acquisition mode and controlled by the FlexControl 3.3 software package. All spectra were obtained using the reflectron mode with an acceleration voltage of $25 \mathrm{kV}$, a reflector voltage of 26, and pulsed ion extraction of $40 \mathrm{~ns}$ in the positive ion mode. The acquisition range used was from $\mathrm{m} / \mathrm{z} 300$ to 3,000 . The data was collected from averaging 400 laser shots, with the lowest laser energy necessary to obtain sufficient signal-to-noise ratios. Peak lists were generated from the MS spectra using Bruker FlexAnalysis software (Bruker Daltonics GmbH, Bremen, Germany) (Version 3.3).

\section{Additional files}

Additional file 1: Figure S1. Linear regression analysis of 2-colour combinations of $\mathrm{CPH}$ substrates. The graphs show linear regression analysis from spectra of two-colour combinations of degradation products (the supernatant) from $\mathrm{CPH}$-xylan mixed in ratios from $0 \%$ to $100 \%$ for each. The deviation of the data points from the line shows deviation from linearity. The results of this analysis show that the true ratio can be determined using linear regression within a $\pm 5 \%$ error margin.

Additional file 2: Figure S2. Reproducibility of the high-throughput assay using $\mathrm{CPH}$ substrates. (A) Four identical reaction plates were set up as shown. The substrates in the reaction plate are shown to the left, and the enzymes in the reaction plate are shown to the right. The substrates used were red $\mathrm{CPH}$-arabinan, green $\mathrm{CPH}$-xylan, yellow $\mathrm{CPH}-\mathrm{HE}$ cellulose, blue $\mathrm{CPH}-\beta$-glucan, red $\mathrm{CPH}$-pectic galactan, green $\mathrm{CPH}$-lichenan, red $\mathrm{CPH}-x y l o g l u c a n$ and yellow $\mathrm{CPH}$-galactomannan. The enzymes used were arabinanase (ara), xylanase ( $x y / 1)$, glucanase (g/c), galactanase (gal), lichenanase (lic) xyloglucanase $(x g)$ and mannanase (man). (B) The four product plates containing the products from the four separate reaction plates. (C) Graph showing the mean absorbances from the product plates (measured at $\lambda_{\max }$ for each substrate colour). See Tables 1 and 2 for details of the substrates and enzyme used. The reaction was performed for $30 \mathrm{~min}$ at room temperature in $100 \mathrm{mM}$ sodium acetate buffer $\mathrm{pH} 4.5$ for ara, $x y / 1$, glc and gal, in $100 \mathrm{mM}$ sodium phosphate buffer $\mathrm{pH} 7.0$ for lic and man and in $100 \mathrm{mM}$ sodium acetate buffer $\mathrm{pH} 5.5$ for $\mathrm{xg}$.

Additional file 3: Figure S3. $\mathrm{pH}$ and temperature stability of $\mathrm{CPH}$ substrates. (A) Graph showing $\mathrm{pH}$ responses for green $\mathrm{CPH}-\mathrm{HE}$ cellulose and green $\mathrm{CPH}$-rhamnogalacturonan treated with a cellulase (cel2) and a pectinase (pec1), respectively, to show the usage of the $\mathrm{CPH}$ substrates at a $\mathrm{pH}$ range between $\mathrm{pH} 3.0$ to 10.0. The assay was performed with $1 \mathrm{U} /$ $\mathrm{mL}$ enzyme concentration in $100 \mathrm{mM}$ Britton-Robinson buffer at room temperature for $30 \mathrm{~min}$. (B) Graph showing a temperature stability test. Green $\mathrm{CPH}-x y l a n$ was treated with a thermophilic xylanase $(x y / 3,0.1 \mathrm{U} /$ $\mathrm{mL}$ ) in sodium acetate buffer $\mathrm{pH} 6.0$ for $1 \mathrm{~h}$ from $20^{\circ} \mathrm{C}$ to $80^{\circ} \mathrm{C}$. See Tables 1 and 2 for details of the substrates and enzyme used.

Additional file 4: Figure S4. Mass spectra of products from $\mathrm{CPH}-x y l a n$ digestion. (A) Mass spectrum of dyed $\mathrm{CPH}$-xylan digested by xylanase $x y / 1$ where the oligomers are composed of $x$ pentose units and $y$ hydrolysed linker units (Pentxlinkery). (B) Mass spectrum of undyed cross-linked xylan digested by xylanase $x y / 1$ where the oligomers are composed of $x$ pentose units and $y$ hydrolysed linker units (Pent linker $_{y}$ ). (C) Theoretical scheme showing the possible origins of the products observed in (A) and (B).

Additional file 5: Figure S5. Storage stability of $\mathrm{CPH}$ substrates. The storage stability of CPH substrates was tested by comparing the output 
from fresh and year-old reaction plates. (A) Images showing products from fresh and year-old reaction plates in which each well contained a mixture of the substrates shown to the right. The enzymes used are indicated at the top. (B) Another second example of an experiment comparing the output from fresh and year-old plates. Each well contained a mixture of the substrates shown to the right. The enzymes used are indicated at the top. See Tables 1 and 2 for details of the substrates and enzyme used.

Additional file 6: Figure S6. Using CPH substrates to analyse enzyme activity in crude fungal broths. The two pathogenic fungi Penicillium expansum and Colletotrichum acutatum were cultivated over 10 days, and enzyme activities in the culture broth were analysed using four different $\mathrm{CPH}$ substrates: (A) yellow $\mathrm{CPH}$-galactomannan, (B) yellow $\mathrm{CPH}$-lichenan, (C) yellow CPH- $\beta$-glucan from barley, (D) yellow CPH-arabinoxylan. As a negative control, the substrates were also treated with broth alone (grey lines). The reaction was incubated in $100 \mathrm{mM}$ sodium acetate buffer $\mathrm{pH} 4.5$ for $1 \mathrm{~h}$ at room temperature. See Table 2 for details of the substrates used.

Additional file 7: Figure S7. Insoluble chromogenic biomass substrates. A range of insoluble chromogenic biomass substrates were produced (all using a red-coloured dye) and treated with a range of enzymes (shown on $x$-axes). The absorbance values are means from three wells measured at $517 \mathrm{~nm}$. Enzymes were used at $10 \mathrm{U} / \mathrm{mL}$ for $24 \mathrm{~h}$ at room temperature. The assay was performed using $100 \mathrm{mM}$ sodium acetate buffer $\mathrm{pH} 4.5$, except for the enzymes ply1, ply2, ply3, pol1 and $x g$ used at pH 5.5, for cel2 pH 6.0, for pec3 $100 \mathrm{mM}$ sodium phosphate pH 7.0 and for pec1 sodium carbonate $\mathrm{pH}$ 10.0. The substrates used were (A) tobacco, (B) Arabidopsis, (C) wheat straw, (D) bagasse, (E) hemp, (F) willow, (G) fenugreek seeds and (H) lupin seeds. See Table 2 for details of the enzyme used.

Additional file 8: Figure S8. MALDI-ToF MS spectra of released products during enzyme treatments of insoluble chromogenic biomass substrates. (A) MALDI-ToF MS spectra of the products released from hemp insoluble chromogenic biomass substrates treated with xylanase xyl1. (B) MALDI-ToF MS spectra of the products released from bagasse treated with xylanase $n z 2$. MeGlcA Pent $_{y}$ represent oligosaccharides with $x$ number of 4-methyl-glucuronic acid and $y$ number of xylose residues; Pent $_{x}=$ pentose oligosaccharides (most likely (arabino-) xylooligosaccharides, arabinosylations limiting complete degradation by the endoxylanases $x y / 1$ and $n z 2$ ) containing $x$ number of pentoses; asterisk $\left(^{*}\right)$ represents sodium adducts, which commonly occur for uronic acids.

\section{Abbreviations}

AZCL: azurine cross-linked; $\mathrm{CPH}$ : chromogenic polysaccharide hydrogel; GAX: glucuronoarabinoxylan; GH: glycosyl hydrolase; ICB: insoluble chromogenic biomass; LPMO: lytic polysaccharide monooxygenase; MALDI-ToF-MS: matrix-assisted laser desorption/ionization-time-of-flight-mass spectrometry; SEM: standard error of mean.

\section{Competing interests}

The authors declare that they have no competing interests.

\section{Authors' contributions}

SKK synthesised the CPH and ICB substrates, performed synthetic optimisations required for their optimal physicochemical performance, purified them and performed some of the analytical experiments. JS designed the assay development for using CPH and ICB substrates in a 96-well plate format and developed the performance in agar plates, did the optimisation and validation of the assays and studied the stability of the substrates as well as the reproducibility of the assay performance. BW performed the mass spectrometry analysis and provided some of the raw biomass material and LGT performed the linear regression analysis. RNM provided enzymes $n z l$ to $n z 4$ and provided reducing end assay activity information, VGHE participated in designing the study and assisted with writing the manuscript and WGTW wrote the manuscript and designed the study. All authors read and approved the final manuscript.

\section{Acknowledgements}

This work was funded by the Danish Council for Strategic Research (DSF, SET4Future project), by the Norwegian Research Council, grant numbers 214613 and 221568 and by the Seventh Framework Programme of the European Union (FP7 2007-2013) under Grant Agreements N263916 (WallTraC project) and N308363 (project Waste2Go). This paper reflects the authors' views only. The European Union is not liable for any use that may be made of the information contained herein. We thank Birgit Jensen and Daniel Buchvaldt Amby for providing the two fungi Colletotrichum acutatum (isolate SA 0-1) and Penicillium expansum (isolate IK2020) and their assistance in cultivation. A patent application related to the assays described in this study (patent application number PA 2013 70507) has been filed.

\section{Author details}

'Department of Plant and Environmental Sciences, Thorvaldsensvej 40, Frederiksberg C 1871, Denmark. ${ }^{2}$ Department of Chemistry, Biotechnology and Food Science, Norwegian University of Life Sciences, Chr. M. Falsens vei 1., Aas 1432, Norway. ${ }^{3}$ University of Copenhagen, Faculty of Science, Rolighedsvej 23, Frederiksberg C 1958, Denmark. ${ }^{4}$ Novozymes A/S, Krogshoejvej 36, Bagsværd 2880, Denmark.

Received: 27 January 2015 Accepted: 30 March 2015

Published online: 23 April 2015

\section{References}

1. Tamayo-Ramos JA, Orejas M. Enhanced glycosyl hydrolase production in Aspergillus nidulans using transcription factor engineering approaches. Biotechnol Biofuels. 2014;7. doi:Artn 103

2. Li LL, McCorkle SR, Monchy S, Taghavi S, van der Lelie D. Bioprospecting metagenomes: glycosyl hydrolases for converting biomass. Biotechnol Biofuels. 2009;2. doi:Artn 10

3. Dimarogona M, Topakas E, Christakopoulos P. Recalcitrant polysaccharide degradation by novel oxidative biocatalysts. Appl Microbiol Biot. 2013;97(19):8455-65. doi:10.1007/s00253-013-5197-y.

4. Agger JW, Isaksen T, Varnai A, Vidal-Melgosa S, Willats WGT, Ludwig R, et al. Discovery of LPMO activity on hemicelluloses shows the importance of oxidative processes in plant cell wall degradation. Proc Natl Acad Sci U S A. 2014;111(17):6287-92. doi:10.1073/pnas.1323629111.

5. Sanchez OJ, Cardona CA. Trends in biotechnological production of fuel ethanol from different feedstocks. Bioresource Technol. 2008;99(13):5270-95. doi:10.1016/j.biortech.2007.11.013.

6. Sweeney MD, Xu F. Biomass converting enzymes as industrial biocatalysts for fuels and chemicals: recent developments. Catalysts. 2012;2(2):244-63. doi:10.3390/Catal2020244.

7. Sims REH, Mabee W, Saddler JN, Taylor M. An overview of second generation biofuel technologies. Bioresource Technol. 2010;101(6):1570-80 doi:10.1016/j.biortech.2009.11.046.

8. Cantarel BL, Coutinho PM, Rancurel C, Bernard T, Lombard V, Henrissat B. The carbohydrate-active enZymes database (CAZy): an expert resource for glycogenomics. Nucleic Acids Res. 2009;37(Database issue):D233-8. doi:10.1093/nar/gkn663.

9. Davies G, Henrissat B. Structures and mechanisms of glycosyl hydrolases. Structure. 1995;3(9):853-9. doi:10.1016/S0969-2126(01)00220-9.

10. Henrissat B. A classification of glycosyl hydrolases based on amino-acid-sequence similarities. Biochem J. 1991;280:309-16.

11. Henrissat B, Bairoch A. New families in the classification of glycosyl hydrolases based on amino-acid-sequence similarities. Biochem J. 1993;293:781-8.

12. Henrissat B, Bairoch A. Updating the sequence-based classification of glycosyl hydrolases. Biochem J. 1996;316:695-6.

13. Henrissat B, Davies G. Structural and sequence-based classification of glycoside hydrolases. Curr Opin Struc Biol. 1997;7(5):637-44. doi:10.1016/S0959-440x(97)80072-3.

14. Pena MJ, Tuomivaara ST, Urbanowicz BR, O'Neill MA, York WS. Methods for structural characterization of the products of cellulose-and xyloglucan-hydrolyzing enzymes. Cellulases. 2012;510:121-39. doi:10.1016/B978-0-12-415931-0.00007-0.

15. Nelson N. A photometric adaptation of the Somogyi method for the determination of glucose. J Biol Chem. 1944;153(2):375-80.

16. Miller GL. Use of dinitrosalicylic acid reagent for determination of reducing sugar. Anal Chem. 1959;31(3):426-8. doi:10.1021/Ac60147a030. 
17. Lever M. Colorimetric and fluorometric carbohydrate determination with para-hydroxybenzoic acid hydrazide. Biochem Med Metab B. 1973;7(2):274-81. doi:10.1016/0006-2944(73)90083-5.

18. Anthon GE, Barrett DM. Determination of reducing sugars with 3-methyl-2benzothiazolinonehydrazone. Anal Biochem. 2002;305(2):287-9.

19. Gusakov AV, Kondratyeva EG, Sinitsyn AP. Comparison of two methods for assaying reducing sugars in the determination of carbohydrase activities. Int J Anal Chem. 2011. doi:Artn 283658

20. Biely P, Mastihubova M, Tenkanen M, Eyzaguirre J, Li XL, Vrsanska M. Action of xylan deacetylating enzymes on monoacetyl derivatives of 4-nitrophenyl glycosides of beta-D-xylopyranose and alpha-L-arabinofuranose. J Biotechnol. 2011;151(1):137-42. doi:10.1016/j.jbiotec.2010.10.074.

21. Ferrari AR, Gaber $Y$, Fraaije MW. A fast, sensitive and easy colorimetric assay for chitinase and cellulase activity detection. Biotechnol Biofuels. 2014;7. doi:Artn 37 doi:10.1186/1754-6834-7-37.

22. Li LL, Taghavi S, McCorkle SM, Zhang YB, Blewitt MG, Brunecky R et al. Bioprospecting metagenomics of decaying wood: mining for new glycoside hydrolases. Biotechnol Biofuels. 2011;4. doi:Artn 23 doi:10.1186/1754-6834-4-23

23. Nyyssonen M, Tran HM, Karaoz $U$, Weihe $C$, Hadi MZ, Martiny JBH et al. Coupled high-throughput functional screening and next generation sequencing for identification of plant polymer decomposing enzymes in metagenomic libraries. Front Microbiol. 2013;4. doi:Artn 282 doi:10.3389/Fmicb.2013.00282

24. Leemhuis H, Kragh KM, Dijkstra BW, Dijkhuizen L. Engineering cyclodextrin glycosyltransferase into a starch hydrolase with a high exo-specificity. J Biotechnol. 2003;103(3):203-12. doi:10.1016/S0168-1656(03)00126-3.

25. Zantinge $J$, Huang HC, Cheng KJ. Microplate diffusion assay for screening of beta-glucanase-producing microorganisms. Biotechniques. 2002;33(4):798

26. Ceska M. A new type of reagent for the detection of molecular varieties of some hydrolytic enzymes: detection of -amylase isoenzymes. Biochem J. 1971;121(3):575-6.

27. Huang JS, Tang J. Sensitive assay for cellulase and dextranase. Anal Biochem. 1976;73(2):369-77.

28. Leisola M, Linko M. Determination of the solubilizing activity of a cellulase complex with dyed substrates. Anal Biochem. 1976;70(2):592-9.

29. Kamaryt J, Zemek J, Kuniak L. Determination of the molecular weight of alpha-amylase, as the enzyme-inhibitor complex, using thin layer gel filtration on Sephadex. J Clin Chem Clin Biochem Zeitschrift fur klinische Chemie und klinische Biochemie. 1982;20(6):451-5.

30. Ten LN, Im WT, Kim MK, Kang MS, Lee ST. Development of a plate technique for screening of polysaccharide-degrading microorganisms by using a mixture of insoluble chromogenic substrates. J Microbiol Meth. 2004;56(3):375-82. doi:10.1016/j.mimet.2003.11.008

31. Ten LN, Im WT, Kim MK, Lee ST. A plate assay for simultaneous screening of polysaccharide- and protein-degrading micro-organisms. Lett Appl Microbiol. 2005:40(2):92-8. doi:10.1111/j.1472-765X.2004.01637.x.

32. Lippa KA, Roberts AL. Nucleophilic aromatic substitution reactions of chloroazines with bisulfide (HS-) and polysulfides (S(n)2(-)). Environ Sci Technol. 2002;36(9):2008-18. doi:10.1021/Es011255v.

33. Biswal AK, Soeno K, Gandla ML, Immerzeel P, Pattathil S, Lucenius J et al. Aspen pectate lyase PtxtPL1-27 mobilizes matrix polysaccharides from woody tissues and improves saccharification yield. Biotechnol Biofuels. 2014;7. doi:Artn 11 doi:10.1186/1754-6834-7-11

34. Van Acker R, Vanholme R, Storme V, Mortimer JC, Dupree P, Boerjan W. Lignin biosynthesis perturbations affect secondary cell wall composition and saccharification yield in Arabidopsis thaliana. Biotechnol Biofuels. 2013;6. doi:Artn 46 doi:10.1186/1754-6834-6-46

35. Darvill JE, Mcneil M, Darvill AG, Albersheim P. Structure of plant-cell walls.11. Glucuronoarabinoxylan, a 2nd hemicellulose in the primary-cell walls of suspension-cultured sycamore cells. Plant Physiol. 1980;66(6):1135-9. doi:10.1104/Pp.66.6.1135.

36. Degroot B, Vandam JEG, Vantriet K. Alkaline pulping of hemp woody core - kinetic modeling of lignin, xylan and cellulose extraction and degradation. Holzforschung. 1995;49(4):332-42. doi:10.1515/hfsg.1995.49.4.332.

37. Smith DC, Forsberg CW. Alpha-glucuronidase and other hemicellulase activities of fibrobacter-succinogenes-\$85 grown on crystalline cellulose or ball-milled barley straw. Appl Environ Microb. 1991;57(12):3552-7.
38. Biely P, Cziszarova M, Uhliarikova I, Agger JW, Li XL, Eijsink VGH, et al. Mode of action of acetylxylan esterases on acetyl glucuronoxylan and acetylated oligosaccharides generated by a GH10 endoxylanase. Bba-Gen Subjects. 2013;1830(11):5075-86. doi:10.1016/j.bbagen.2013.07.018.

39. Vidal-Melgosa S, Pedersen HL, Schückel J, Arnal G, Dumon C, Amby DB et al. A new versatile microarray-based method for high-throughput screening of carbohydrate-active enzymes. The Journal of biological chemistry. 2015. doi:10.1074/jbc.M114.630673.

\section{Submit your next manuscript to BioMed Central and take full advantage of:}

- Convenient online submission

- Thorough peer review

- No space constraints or color figure charges

- Immediate publication on acceptance

- Inclusion in PubMed, CAS, Scopus and Google Scholar

- Research which is freely available for redistribution 